\title{
Does hyaluronic acid decrease the apoptotic effect of bupivacaine?
}

\author{
Hiyalüronik asit bupivakainin apoptotik etkisini azaltır mı?
}

\author{
İrfan Güngör, M.D., ${ }^{1}$ Akın Yılmaz, M.D., ${ }^{2}$ Mehmet Ali Ergün, M.D., ${ }^{3}$ \\ Akif Muhtar Öztürk, M.D., ${ }^{4}$ Kadir Kaya, M.D. ${ }^{1}$ \\ 1Department of Anesthesiology and Reanimation, Medical Faculty of Gazi University, Ankara, Turkey
'Department of Medical Biology and Genetics, Medical Faculty of Gazi University, Ankara, Turkey
${ }^{3}$ Department of Medical Genetics, Medical Faculty of Gazi University, Ankara, Turkey
Department of Orthopedics and Traumatology, Medical Faculty of Yeditepe University, Ankara, Turkey
}

Objectives: In this study, we aimed to study the antiapoptotic effects of hyaluronic acid on the apoptotic effects of bupivacaine in cultured rat chondrocytes in a time and dosedependent manner.

Material and methods: The rat chondrocytes were treated with $7.69 \mu \mathrm{M}, 76.9 \mu \mathrm{M}$, and $384.5 \mu \mathrm{M}$ bupivacaine and $50 \mu \mathrm{g} / \mathrm{ml}$ hyaluronic acid concentrations for six, 24, and 48 hours. At the end of the treatment period, cells were stained with mixture of acridine orange and ethidium bromide. Apoptosis was evaluated using a fluorescence microscope.

Results: A significant protective effect of hyaluronic acid on chondrocytes against bupivacaine exposure at $7.69 \mu \mathrm{M}$ and $76.9 \mu \mathrm{M}$ concentrations, particularly was observed. There was also a significant protective effect in the exposure time at six and 24 hours for $7.69 \mu \mathrm{M}$ and $76.9 \mu \mathrm{M}$ bupivacaine doses.

Conclusion: Our study results show that hyaluronic acid against chondrotoxicity of bupivacaine may have a protective effect in a time and dose-dependent manner.

Keywords: Apoptosis; bupivacaine; chondrocyte; hyaluronic acid.

Bupivacaine has been used in orthopedic patients as a local analgesic agent following arthroscopic

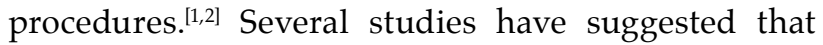
bupivacaine may cause a significant decrease in chondrocyte function and viability after short-term exposures in a time and dose-dependent manner. ${ }^{[3]}$
Amaç: Bu çalışmada, bupivakainin kültüre edilmiş sıçan kondrositleri üzerindeki apoptotik etkisine zaman ve doza bağlı olarak hiyalüronik asitin anti-apoptotik etkisi araştırıldı.

Gereç ve yöntemler: Siçan kondrositleri, $7.69 \mu \mathrm{M}, 76.9 \mu \mathrm{M}$ ve $384.5 \mu \mathrm{M}$ bupivakain ile $50 \mu \mathrm{g} / \mathrm{ml}$ hiyalüronik asit konsantrasyonları ile altı, 24 ve 48 saatlik sürelerde uygulandı. Tedavi süresi sonunda hücreler akridin turuncusu karışımı ve etidium bromid ile boyandi. Apoptoz floresan mikroskobu ile değerlendirildi.

Bulgular: Kondrositlerde özellikle $7.69 \mu \mathrm{M}$ ve $76.9 \mu \mathrm{M}$ konsantrasyonlarında hyalüronik asitin bupivakanin toksik etkisine karşı anlamlı bir koruyucu etki gösterdiği gözlendi. Ayrica altı ve 24. saatte $7.69 \mu \mathrm{M}$ ve $76.9 \mu \mathrm{M}$ bupivakain dozlarında maruziyet süresi açısından anlamlı bir koruyucu etki tespit edildi.

Sonuç: Çalıșma sonuçlarımız, hiyalüronik asidin bupivakainin kondrotoksik özelliğine karşı zaman ve doza bağımlı bir şekilde koruyucu etkisi olabileceğini göstermektedir.

Anahtar sözcükler: Apoptoz; bupivakain; kondrosit; hiyalüronik asit.

Bupivacaine has been shown as having the most severe cytotoxic effects among the readily available local anesthetics. ${ }^{[4]}$

Previous studies have demonstrated that bupivacaine induces apoptosis in human fibroblasts, lymphocytes and rat chondrocytes in a time and

- Received: March 14, 2014 Accepted: May 16, 2014

- Correspondence: İrfan Güngör, M.D. Gazi Üniversitesi Tıp Fakültesi Anesteziyoloji ve Reanimasyon Anabilim Dalı, 06500 Beşevler, Ankara, Turkey. Tel: +90 312 - 2024637 Fax: +90 312- 2024635 e-mail: irserkez@yahoo.co.uk 
dose-dependent manner. ${ }^{[5,6]}$ In addition, lidocaine, bupivacaine, and ropivacaine have been reported to cause delayed mitochondrial dysfunction and apoptosis in cultured human chondrocytes. ${ }^{[7]}$

Hyaluronic acid naturally occurring high molecular weight glycosaminoglycan, secreted in synovial joints and aids normal joint lubrication. ${ }^{[8]}$ It has unique properties including viscosity, lack of immunogenicity, and biocompatibility. The formulations of local anesthetics with hyaluronic acid have been reported to induce prolonged analgesia. ${ }^{[9]}$

In a study, hyaluronic acid suppressed chondrocyte apoptosis in a dose-dependent manner in an interleukin (IL)-1beta-induced osteoarthritis model ${ }^{[10]}$ Cross-linkable hyaluronic acid appears to be a safe and effective means of prolonging the duration of block of local anesthetics that merits further investigation for clinical applicability. ${ }^{[1]}$ Also, the prolongation of epidural bupivacaine by hyaluronic acid viscous formulations has been demonstrated. ${ }^{[9]}$

In this study, we aimed to investigate the antiapoptotic effect of hyaluronic acid on the apoptotic effects of bupivacaine in cultured rat chondrocytes in a time and dose-dependent manner.

\section{MATERIAL AND METHODS}

Chondrocytes were isolated from the articular cartilages of the rats. Donor rat was randomly picked up from the control group of another study at the time of scheduled sacrification under ketamine anesthesia. No treatment or medication was given during the study period. Harvested cells were Dulbecco's modified Eagle medium (DMEM) supplemented with $10 \%$ fetal calf serum, $1 \%$ penicillin/streptomycin and $200 \mathrm{mM}$ l-glutamine in humidified air atmosphere of $5 \% \mathrm{CO}_{2}$ at $37^{\circ} \mathrm{C}$. Cell viability was determined by trypan blue dye exclusion method.

A pilot study was conducted for 25, 50, and $100 \mu \mathrm{g} / \mathrm{ml}$ hyaluronic acid concentrations to examine the effective dose of hyaluronic acid. There was no significant difference in the apoptosis and necrosis ratios among 25, 50, and $100 \mu \mathrm{g} / \mathrm{ml}$ hyaluronic acid treatment groups at respective time points. For practical reasons, only $50 \mu \mathrm{g} / \mathrm{ml}$ concentrations of hyaluronic acid was combined with bupivacaine concentrations for remaining of the study. Cells were treated with 7.69, 76.9, and $384.5 \mu \mathrm{M}$ bupivacaine and $50 \mu \mathrm{g} / \mathrm{ml}$ hyaluronic acid concentrations for six, 24 , and 48 hours. In the evaluation of hyaluronic acid and bupivacaine combination, cells were treated with $50 \mu \mathrm{g} / \mathrm{ml}$ of hyaluronic acid (Hyalgan, Fidia Farmaceutici S.p.A, Padua, Italy) (HA)1 h prior to the
7.69, 76.9, and $384.5 \mu \mathrm{M}$ bupivacaine administration. There were eight treatment groups including the control for each time point. Each study group was repeated for three times and separately evaluated for statistical analyses.

After given treatments, cells were centrifuged at $1200 \mathrm{rpm}$ for 10 minutes. Pellets were collected on a glass slide and stained with $1 \mu \mathrm{L}$ of a mixture of acridine orange $(100 \mu \mathrm{g} / \mathrm{mL}$ in PBS, Sigma A-6014) and ethidium bromide $(100 \mu \mathrm{g} / \mathrm{mL}$ in PBS, Sigma E-8751). Then, cells were immediately examined under a fluorescence microscope at a $490 \mathrm{~nm}$ excitation wavelength.

Acridine orange enters cells through an intact cytoplasmic membrane and intercalates into DNA making it appear green, with structure variations in fluorescence intensity in normal nuclei due to the relative distribution of euchromatin and heterochromatin. In contrast, apoptotic nuclei have condensed chromatin, which is uniformly stained, and takes the form of crescent or numerous featureless bright spherical bodies. Passive diffusion of acridine orange induces green cytoplamic coloration. Ethidium bromide is only taken up by cells with a damaged cytoplasmic membrane and stains the nucleus in red with the same characteristic apoptotic features in the case of secondary necrosis or intact nuclear structure incell death due to primary necrosis. ${ }^{[12]}$

\section{Statistical analysis}

Data sets obtained from cell cultures after six, 24, 48 hours of treatment were individually analyzed. Kruskal Wallis and Mann-Whitney U test, one way ANOVA, independent samples t-test and paired samples t-test with Bonferroni correction were used to analyze statistical significance among treatment groups and different time points. Statistical analysis was performed with SPSS version 17.0 for Windows (SPSS Inc., Chicago, IL, USA), and $\mathrm{p}<0.05$ was accepted as statistically significant.

\section{RESULTS}

There was no significant difference in the apoptosis and necrosis ratios among 25, 50, and $100 \mu \mathrm{g} / \mathrm{ml}$ hyaluronic acid treatment groups at respective time points, $(\mathrm{p}>0.05)$. For practical reasons, only $50 \mu \mathrm{g} / \mathrm{ml}$ concentrations of hyaluronic acid were combined with bupivacaine concentrations for remaining of the study.

Within the first 24 hours of treatment, at six and 24 hours particularly,' addition of hyaluronic acid to the culture did not affect the chondrocyte apoptosis and necrosis $(\mathrm{p}<0.05)$. At 48 hours, 
hyaluronic acid-treated groups showed a significant decrease in apoptosis and cell necrosis $(p<0.05)$. Both 7.69 and $76.9 \mu \mathrm{M}$ bupivacaine doses cell viabilities were significantly higher than their corresponding treatment groups without hyaluronic acid ( $\mathrm{p}>0.05)$.

There was a statistical significance between bupivacaine and (bupivacaine and hyaluronic acid) treatment groups at 7.69, 76.9, and $384.5 \mu \mathrm{M}$ concentrations at six hours $(\mathrm{p}<0.05)$. At 24 hours, there was a statistical significance only at $7.69 \mu \mathrm{M}$ concentration of bupivacaine $(\mathrm{p}<0.05)$. We also compared the time-dependency of these concentrations and observed a statistical significance between six over 24 hours and six over 48 hours at doses of $7.69 \mu \mathrm{M}$ and $76.9 \mu \mathrm{M}$ of bupivacaine and bupivacaine + hyaluronic acid treatments $(\mathrm{p}<0.05)$. After 24 hours of treatment, all cells were necrotic at $384.5 \mu \mathrm{M}$ in bupivacaine-treated groups (Table 1 and Figure 1).

\section{DISCUSSION}

The present study clearly demonstrate that combination of bupivacaine with hyaluronic acid prevents apoptotic effect of bupivacaine on cultured rat chondrocytes by time and dose-dependent manner to a certain aspect. Treatment of chondrocytes with hyaluronic acid one hour prior to the administration of bupivacaine revealed a significant protective effect at $7.69 \mu \mathrm{M}$ and $76.9 \mu \mathrm{M}$ concentrations of bupivacaine, in particular. Concerning exposure time to bupivacaine, there was a significant protection at six and 24 hours for $7.69 \mu \mathrm{M}$ and $76.9 \mu \mathrm{M}$ doses of bupivacaine.

Daily practice of intra-articular administration of bupivacaine for postoperative analgesia is usually performed. ${ }^{[1,2]}$ In addition, we demonstrated that detrimental effects of bupivacaine cultured chondrocytes were dose dependent, and lessened only below $7.69 \mu \mathrm{M}$ concentration, and after 24 hours of exposure toxic effects drastically hastened. ${ }^{[5,6]}$ Therefore, we aimed to examine short term effects of bupivacaine and hyaluronic acid combination in terms of chondrotoxicity.

The toxic effect of LA on target cells manifest themselves as apoptosis. Apoptosis is a genetically programmed mechanism of cell death often characterized by inter-nucleosomal DNA cleavage. ${ }^{[13]}$ Chromatin fragmentation and condensation, cell shrinkage, membrane blebbing, and disintegration of cell integrity as membrane-bound pyknotic apoptotic bodies are defined to be distinct features of apoptotic cell death. ${ }^{[14]}$

It has also been reported that hyaluronic acid with bupivacaine prolonged the tetrodotoxininduced conduction blockade of the aortic nerve of rabbits in vivo. ${ }^{[15]}$ The cross-linked hyaluronic acid formulation increased the duration of block across a range of clinically relevant concentrations of bupivacaine. ${ }^{[1]]}$ Viscous hyaluronic acid formulations prolonged the effect bupivacaine as observed in rabbits. ${ }^{[16]}$

Hyaluronic acid is an unsulfated glycosaminoglycan polysaccharide composed of glucuronic acid and $\mathrm{N}$-acetylglucosamine. It protects chondrocytes from proteoglycan depletion and cytotoxic effects of oxygen derived free radicals. ${ }^{[17]}$ Physiologically around $95 \%$ of bupivacaine and analogs bind to proteins, while the remaining 5\% exert clinical effects. ${ }^{[18]}$ Following joint surgeries, most of the macro-molecules including hyaluronic acid within the joint are washed out. As a consequence, tissue would be exposed to a toxic

TABLE I

Apoptotic ratios of chondrocytes after treatment with bupivacaine and hyaluronic acid

\begin{tabular}{|c|c|c|c|c|c|c|}
\hline \multirow{3}{*}{ Concentration } & \multicolumn{2}{|l|}{6 Hours } & \multicolumn{2}{|c|}{24 Hours } & \multicolumn{2}{|c|}{48 Hours } \\
\hline & Apoptosis (\%) & $p$ & Apoptosis (\%) & $p$ & Apoptosis (\%) & $p$ \\
\hline & Mean $\pm S D$ & & Mean $\pm S D$ & & Mean \pm SD & \\
\hline $7.69 \mu \mathrm{M}$ Bupivacaine & $17.1 \pm 2.91$ & & $36.6 \pm 1.73$ & & $32.2 \pm 3.03$ & \\
\hline $76.9 \mu \mathrm{M}$ Bupivacaine & $40.2 \pm 2.96$ & & $23.2 \pm 2.99$ & & $-^{*}$ & \\
\hline $384.5 \mu \mathrm{M}$ Bupivacaine & $30.2 \pm 2.81$ & & $-^{*}$ & & $-{ }^{*}$ & \\
\hline $7.69 \mu \mathrm{M}$ Bupivacaine $+50 \mu \mathrm{g} / \mathrm{ml} \mathrm{HA}$ & $3.6 \pm 2.2$ & $<0.05^{\star *}$ & $17.1 \pm 4.6$ & $<0.05^{\star}$ & $21.6 \pm 7.1$ & $>0.05^{\star *}$ \\
\hline $76.9 \mu \mathrm{M}$ Bupivacaine $+50 \mu \mathrm{g} / \mathrm{ml} \mathrm{HA}$ & $6.0 \pm 2.5$ & $<0.05 \ddagger$ & $16.9 \pm 5.6$ & $>0.05 b$ & $29.4 \pm 7.5$ & \\
\hline $384.5 \mu \mathrm{M}$ Bupivacaine $+50 \mu \mathrm{g} / \mathrm{ml} \mathrm{HA}$ & $18.2 \pm 4.18$ & $<0.05 \S$ & $-{ }^{*}$ & & $-^{*}$ & \\
\hline
\end{tabular}

SD: Standard deviation; *: There is no data obtained because of the necrosis; ${ }^{* *}$ : As compared to the $7.69 \mu \mathrm{M}$ Bupivacaine; $\neq$ : As compared to the $76.9 \mu \mathrm{M}$ Bupivacaine; $\S$ : As compared to the $384.5 \mu \mathrm{M}$ Bupivacaine; HA: Hyaluronic acid. 

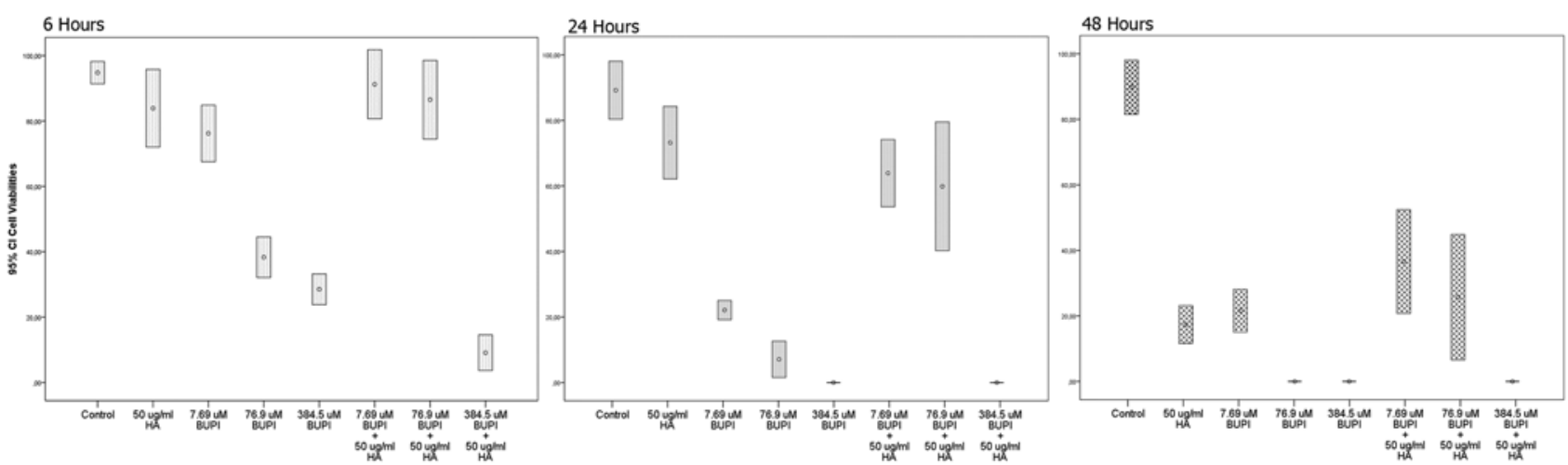

Figure 1. Graph demonstrating the percentage of viability at six, 24 , and 48 hours of treatment for all study groups at $95 \%$ confidence interval for the mean.

amount of administered drugs. Hence, cell culture studies may mimic conditions of postoperative washed out joint environment.

Cell culture studies cannot represent in vivo environments. This preliminary cell culture study also has limitations. Cells were originated from rat cartilage tissue, and the number of cell culture samples was limited. Therefore, current data set cannot be used to make changes in daily medical practice. However, data drawn from current work denotes; bupivacaine induced chondrocyte apoptosis can be prevented by combinations of hyaluronic acid, especially during first 24 hours of treatment.

Nonetheless, further studies based on this experimental study are needed to clearly demonstrate protective effects and safety profile of hyaluronic acid against chondrotoxicity of bupivacaine in a time and dose-dependent manner.

\section{Declaration of conflicting interests}

The authors declared no conflicts of interest with respect to the authorship and/or publication of this article.

\section{Funding}

The authors received no financial support for the research and/or authorship of this article.

\section{REFERENCES}

1. Madencioğlu H, Karakas ES, Akın A, Karaoğlu S, Boyacı A. Postoperative effects of intraarticularbupivacaine on pain in arthroscopies. Eklem Hastalik Cerrahisi 1998;9:13-15.

2. Atik OS. Is single-dose local anesthetic chondrotoxic?. [Article in Turkish] Eklem Hastalik Cerrahisi 2012;23:111-2.

3. Liu S, Zhang QS, Hester W, O'Brien MJ, Savoie FH, You Z. Hyaluronan protects bovine articular chondrocytes against cell death induced by bupivacaine at supraphysiologic temperatures. Am J Sports Med 2012;40:1375-83.

4. Carvalho B, Clark DJ, Yeomans DC, Angst MS. Continuous subcutaneous instillation of bupivacaine compared to saline reduces interleukin 10 and increases substance P in surgical wounds after cesarean delivery. Anesth Analg 2010;111:1452-9.

5. Gungor I, Yilmaz A, Ozturk AM, Ergun MA, Menevse S, Kaya K. Bupivacaine and levobupivacaine induce apoptosis in rat chondrocyte cell cultures at ultra-low doses. Eur J Orthop Surg Traumatol 2014;24:291-5.

6. Yilmaz A, Ergun MA, Ozturk AM, Gungor I, Yetkin H, Kaya K. Local anesthetics can induce apoptosis in human fibroblast and lymphocytes. Acta Medica Mediterranea 2013;29:161-5.

7. Grishko V, Xu M, Wilson G, Pearsall AW 4th. Apoptosis and mitochondrial dysfunction in human chondrocytes following exposure to lidocaine, bupivacaine, and ropivacaine. J Bone Joint Surg [Am] 2010;92:609-18.

8. Baker JF, Solayar GN, Byrne DP, Moran R, Mulhall KJ. Analgesic control and functional outcome after knee arthroscopy: results of a randomized double-blinded trial comparing a hyaluronic acid supplement with bupivacaine. Clin J Sport Med 2012;22:109-15.

9. Dollo G, Malinovsky JM, Péron A, Chevanne F, Pinaud M, Le Verge R, et al. Prolongation of epidural bupivacaine effects with hyaluronic acid in rabbits. Int J Pharm 2004;272:109-19.

10. Zhou PH, Liu SQ, Peng H. The effect of hyaluronic acid on IL-1beta-induced chondrocyte apoptosis in a rat model of osteoarthritis. J Orthop Res 2008;26:1643-8.

11. Jia X, Colombo G, Padera R, Langer R, Kohane DS. Prolongation of sciatic nerve blockade by in situ crosslinked hyaluronic acid. Biomaterials 2004;25:4797-804.

12. Swanson SM, Ijaz A, Fahning ML. The use of acridine orange and ethidium bromide to determine the viability of pre-implantation mouse embryos cultured in vitro. Br Vet J 1987;143:306-11.

13. Chu CR, Izzo NJ, Papas NE, Fu FH. In vitro exposure to $0.5 \%$ bupivacaine is cytotoxic to bovine articular chondrocytes. Arthroscopy 2006;22:693-9.

14. Balci A, Sahin FI, Ekmekci A. Gossypol induced apoptosis in the human promyelocytic leukemia cell line HL 60. Tohoku J Exp Med 1999;189:51-7. 
15. Stevens MF, Hoppe M, Holthusen H, Lipfert P. Tetrodotoxin-induced conduction blockade is prolonged by hyaluronic acid with and without bupivacaine. Acta Anaesthesiol Scand 2004;48:128-34.

16. Gianolio DA, Philbrook M, Avila LZ, MacGregor $H$, Duan SX, Bernasconi R, et al. Synthesis and evaluation of hydrolyzable hyaluronan-tethered bupivacaine delivery systems. Bioconjug Chem 2005;16:1512-8.

17. Zhou PH, Liu SQ, Peng H. The effect of hyaluronic acid on IL-1beta-induced chondrocyte apoptosis in a rat model of osteoarthritis. J Orthop Res 2008;26:1643-8.

18. Mazoit JX, Dalens BJ. Pharmacokinetics of local anaesthetics in infants and children. Clin Pharmacokinet 2004;43:17-32. 